\title{
The Philippines as a Case Study- Populism and Institutional Activism in Transformation Processes Towards Sustainability
}

The current resurgence and reinforcement of populists in many countries has profited not only from various real or imagined crises (e.g., 2015-present refugee crisis in Europe or the caravan of migrants in Latin America heading to the United States), but also from how established political parties and polities have addressed these crises, which have disenfranchised, in a de facto manner, a significant portion of the population (see White 2016). Former Greek finance minister and Professor of Economics at the University of Athens, Yanis Varoufakis, notes that President Trump's election, Brexit, and the resurgence of right-wing political parties in Germany, Austria \& other countries are not new in history, but merely "a post-modern variant of the 1930s, complete with deflation, xenophobia, and divide-and-rule politics" (Varoufakis 2016). Populist movements have found and instrumentalized compelling issues, such as emission reduction, to gain political importance. For example, in an attempt to re-gain political importance, they have taken emission reduction as an example of a policy instrument that undermines national interests because they negatively affect job opportunities in various coal-dependent regions.

Many experts (see Storck \& Stehr 2010; Stehr 2015; White 2016) argue that ambitious climate protection measures are also questions of governance and politics. As climate protection policies have become part of the "new normal" and of the mainstream socio-political and sociolinguistic narratives, they have also united and mobilized 'climate change deniers,' critics of the political 'establishment,' nationalists, xenophobes, alt-right groups, and fossil fuel interest groups to pose a coherent and effective political opposition. Because 'climate change policies' and 'climate science' have been mainstreamed or in some cases narrated as 'linked' with liberal ideas in the past few years, questions relevant to climate change have been unintentionally reduced to being only matters of political decisions and actions. With the rise of counter-movements including 
anti-intellectualism and the emergence of the post-truth era, climate science, which has initiated political discussions on climate protection, is being delegitimized by actors in various directions, which is often not hard to do, due to the complexity and uncertainty of climate change as well as due to the conceptual and methodological limitations of scientific methods.

The Philippines and the United States (see Chapter 11) are two of the several countries wherein nationalists and right-wing populists have profited from such anti-intellectualist, anti-democratic, anti-establishment, anti-media, and post-truth movements as well as from the context of the political system. For example, with the absence of a run-off in the electoral system of the Philippines, as the official canvas of the Congress of the Philippines concluded, the populist President Rodrigo Duterte won the presidential election with the second-smallest mandate in Philippine history (Nery 2017), with just 39.01 percent of the counted electoral votes (16,601,997 votes). Rodrigo Duterte's campaign was based on hostility towards the 'West', the corrupt political establishment, the independent press, and on dehumanizing (real and alleged) criminals, including drug addicts.

With several similarities and the parallel development of the Philippines and the United States following the election of a populist leader, this chapter and the following chapter will provide important insights into understanding how a system can adapt to a regime hostile to many principles of sustainable development and climate protection. As a former colony of the United States, the Philippines has a political system that closely resembles that of the United States. A major focus is given to the role of social movements, including non-profits, advocacy groups, non-government organizations or NGOs, and other civil society groups, using an ideal type of the institutional activism-dominated policy model. In the case of the Philippines, populism and institutional activism have merged. Furthermore, the Philippine context challenges the existing 'right-left' dichotomy of political ideology with the 'textbook' right-wing Duterte regime debarring political opposition from the Left by 'subcontracting' certain policies to left-wing actors.

Finding compelling reasons for long-term climate protection under President Duterte is challenging, particularly because the Philippines is not a major emitter of greenhouse gases or GHG. In addition, the sociolinguistic narrative on climate protection in the Philippines is instead focused on climate adaptation. Because the country is one of the most vulnerable to the impacts of climate change, climate protection through emission reduction has not yet caught the attention of policy-makers and the Philippine society in general. The Paris Climate Agreement is generally linked with more international support of adaptation projects in the country. Upon ratification, the Philippines will have access to the Green 
Climate Fund, which will be funded with USD 100 million annually by developed countries to support vulnerable and low-emitting countries confronted with climate change. Therefore, unlike in the United States, populist groups in the Philippines cannot draw more popular support by rejecting the Paris agreement. Despite previous negative comments about the Paris Climate Agreement, President Duterte approved the agreement through his signature and his submission of the instrument of accession to the Philippine Senate for ratification of the Paris Agreement on February 28, 2017 (Salaverria 2017).

An analysis of politics in the Philippines remains interesting, as President Duterte contains political opposition by dividing social movements. After his inauguration, he appointed three left-wing activists to his cabinet, including an environmental activist as Secretary of the Department on Environment and Natural Resources and a social activist as Secretary of the Department of Social Welfare and Development. As part of the social movement, the appointed environment Sec. Gina Lopez has typically used strategies common to advocacy groups in achieving goals.

Furthermore, another unique feature of the Philippine political system has led to the President's control of various social and environmental movements through the party-list system, through which, as mandated by the 1987 constitution (Article VI, Section 5 (i) and 2), 57 seats or 20 percent of the total seats in the House of Representatives are reserved for purportedly under-represented community sectors or groups, including labor, peasant, urban poor, senior citizens, indigenous, women, youth, and other such sectors (see Santos 1997). With elected social interest groups seeking collaboration with the newly elected president to increase the prospect of achieving their interests, social groups that are indifferent to specific issues are involved in 'tit-for-tats'.

While tolerating the appointment and presence of civil-group representatives who were linked with the military, several leftist house representatives, who were elected into the Philippine Congress through the party-list system, have declared their support of President Duterte and informally agreed to a 'truce' with the military. This co-option of various social movements through President Duterte can be interpreted as a strategy to stabilize his political control, as it prevents alliances between major social and environmental groups and the political opposition. With potential challengers, such as opposition politicians, court justices, and human rights commissioners currently in the defensive mode as most of them were removed from positions in important committees in the Senate and House of Representatives, and while some are currently facing impeachment trials or criminal charges or even imprisoned, no viable dissenters can mobilize popular support to the political opposition. 
In addition, the current administration, like previous administrations, is profiting from the incapacities of political and legal constraints provided by state institutions, such as courts and the commission on human rights. This incapacity is further exacerbated by the 'weaponization' of congress' power to impeach (Nery 2017) and of the 'quo warranto'- power of the Solicitor General, as manifested by the recent removal of the Supreme Court Chief Justice on grounds that she failed to submit a requirement prior to her appointment as Chief Justice, making her appointment by former President Benigno Aquino void (see Garcia 2018; Cabuenas 2018).

Further discrediting social movements, a legitimacy crisis within civil society groups emerged following the "pork barrel scam scandal", where politicians allegedly partnered with NGOs to divert and misuse their Priority Development Assistance Fund, popularly called "pork barrel," for personal gains (see Doronila 2013; Ubac 2013). In addition, many civil liberties and rights groups refuse to collaborate with current opposition politicians (or their families), whom they highly criticized when the latter were still in power. The current administration in the Philippines, after it has successfully co-opted major civil society groups represented in the House of Representatives, will most likely not expect a unified political opposition.

The goal of this chapter is to analyze and conceptualize the role of social movements, advocates, non-profits (and to a lesser degree profitable enterprises) and other civil society groups as agents of the transformation process towards sustainability in a political framework or a context that is partially or fully adversarial or hostile towards political deliberation. By understanding the resources and strategies available to these social actors when promoting or encountering policies that are conducive to sustainable, low-carbon development, best practices can be derived. In addition, the comparison of this case study with a theoretical model (ideal type) will be conducted. The Philippine case study will be analyzed using the ideal type of an institutional activism policy model.

Hypothesis 1: Looking at the 'negotiative' requirement of transformation towards sustainability, the benefits and risks of institutional activism and social movements are highly contingent upon existing power relations and structures as well as on the level of capacity and autonomy of the State.

Existing power relations and structures, as well as the level of capacity and autonomy of the state, motivate and alter utility values for advocacy groups and social movements who were embedded into the policy stream. Will the (liberal) normative concerns that often define social movements refrain them from 
instrumentalizing power asymmetries when they are in power? Will they deploy resources in strategic ways and compete with other stakeholders, including other NGOs and other social movements?

Hypothesis 2: While institutional activism can facilitate rapid policy formulation, it can also reinforce existing inequalities in countries with low social capital.

While institutional activists often present their interests and strategies as public interests, gaps between their interests and those of the general public can still exist. In addition, institutional activists may directly or indirectly reinforce existing structural imbalances and equalities when they find themselves in a more powerful position.

\subsection{Context-Sustainable, Low-Carbon Development in the Philippines}

\subsubsection{The Paris Agreement and Responses From the Philippines}

Climate change is evident in the Philippines. From 1951 to 2010 , the Philippines' annual mean temperature increased by 0.65 degrees Celsius with a mean rate of 0.01 degree Celsius per year. Furthermore, records from 1951 to 2008 show increasing intensity and frequency of rainfall in most parts of the country. In addition, based on climate projections, the Philippines' annual mean temperature will increase by 0.9 to 1.1 degrees Celsius in the 2020s, and 1.8-2.2 degrees Celsius in the 2050s (see OML Center 2014).

Addressing climate change in the Philippines is mainly focused on adaptation to the adverse effects of climate change. One viable reason for this is the rather low contribution of the country to global emissions. According to the UNFCCC Secretariat, the Philippines was responsible only for 0.25 percent of global $\mathrm{CO}_{2}$ emissions from fuel combustion (79.5 Mt $\mathrm{CO}_{2}$ Eq.) in 2012, with its population comprising 1.38 percent of world total population in 2013 (98.39 million). Nevertheless, the Philippine Climate Change Assessment Report warns that if the Philippine power sector continues to depend on coal (which covers 39 percent of energy demand), emissions from the Philippines are likely to increase by around 400 percent by the year 2030, compared to 2007 levels (see OML Center 2014). The Philippine government will therefore need to cancel all 29 coal plants currently in the pipeline to stabilize the emission level. 
The government's intention to reduce its carbon emissions by 70 percent by 2030 (DENR 2016) demonstrates a huge gap from the rise of emissions expected by the assessment report. In this regard, more ambitious mitigation measures will be needed. The government is not able to reconcile nor give any concrete means as to how it would mitigate the country's carbon emissions. The Department of Energy defined a policy goal as an energy mix of 30 (coal) - 30 (renewables) - 30 (natural gas) - 10 (fuel oil), but without identifying concrete ways in which the government intends to achieve this goal. Moreover, as discussed earlier, as a weak state, the national government has low capacity and low autonomy to identify and implement projects to achieve this goal, especially in a country where power generation is not considered a public utility. The liberalization of the energy sector further limits the ability of the national government to achieve its mitigation policy goal, especially when the Philippines' largest electricity distributor and the sole provider in the National Capital Region, the Manila Electric Company (MERALCO), has so far only invested in coal power plants (Olchondra 2015; Flores 2017). There are also no clear government strategies as to how it intends to support solar and wind energy and enable new players to enter an energy market where coal is the baseload.

The main mitigation instrument foreseen by the government is increasing carbon sinks by reforestation, which is, in the context of rapid urbanization and the need for more land for agriculture, expected to be not enough. Hence, the mitigation strategy of the Philippines needs to be revisited. For example, there is still no comprehensive and integrated national strategy as to how this intention can be realistically enacted, for example, by linking climate mitigation goals to enhancing renewable energies and energy efficiency. The investments in renewable energies in the Philippines will need to be matched, for example, by investment in infrastructure, such as grid systems in order to address the intermittency challenges of renewable energies. In addition, there is a need to improve the business prospects of mitigation technologies in the country. Finally, a major hurdle that needs to be cleared refers to deficiencies in governance.

As the Philippines is one of the countries most vulnerable to climate change, political priority is instead focused on early-warning and post-disaster management. Furthermore, the country is still working on how to incorporate technologies and improving its disaster risk reduction and management capability. Information asymmetry is still apparent, particularly in cities and rural areas outside the capital region. While the country has significantly improved its disaster preparedness, it is still ranked by the 2016 Climate Change Vulnerability Index as the $13^{\text {th }}$ most climate-vulnerable country (see Ranada 2015). This vulnerability is reflected in the issues pushed by the Philippines during climate negotiations. 
For example, the Philippines led the Climate Vulnerability Forum of almost 50 developing countries in successfully pushing for $1.5^{\circ} \mathrm{C}$ to be recognized as the aspirational target of the UN Paris Agreement, which the Philippines signed last April 2016.

\subsubsection{Sustainable Development Policies in the Philippines}

As one of the 193 member-states that adopted the 2030 Agenda for Sustainable Development in 2015, the Philippines is taking further steps in defining the country's roadmap towards sustainable development in the next 15 years. Together with the Philippine Statistics Authority, the National Economic and Development Authority (NEDA) is the main government body that steers the government's efforts to achieve the 2030 Agenda.

President Duterte has signed Executive Order (EO) No. 5, which provided for the adoption of Ambisyon Natin 2040, as the Philippines 25-year, long-term vision and guide for development planning. It describes the kind of life that people want to live, and how the Philippines will be by 2040. Ambisyon Natin 2040 is a product of a series of nationwide public consultations consisting of focus group discussions participated in by representatives from groups of youth, fishers, farmers, the urban poor, disaster survivors, indigenous peoples, people with disabilities, families of overseas workers, local migrants, and government workers, among others, and the administration of a survey led by NEDA, to determine the aspirations of the Filipino population. A number of technical studies were also commissioned in key thematic areas of development through the support of the Asian Development Bank to understand whether Ambisyon Natin 2040 is achievable and to determine what it would take to achieve the vision. It aims to triple per capita income to 11,000 USD in 24 years by sustaining at least 6.5 percent annual GDP growth alongside the implementation of policies that would make the Philippines a high-income country by 2040 with a "prosperous, predominantly middle-class society where no one is poor."

Nevertheless, the vision does not clearly include the energy sector as among the identified priority sectors, even though the energy sector was involved in the series of nationwide public consultations. While the PDP consists of the government's plans and programs for the energy sector geared towards achieving Ambisyon Natin 2040, the absence of the participation of energy-related stakeholders as well as societal groups addressing energy issues will most likely lead to gaps and missed opportunities. As expected, because of the country's focus on adaptation, it also fails to identify climate protection as an economic opportunity, for example, through energy efficiency technologies. The lack of political involvement in mitigation leaves the country outside the discourse on energy efficiency 
and renewable interests. This leads to the country not fully accessing all available opportunities to enhance energy security. The success of the vision's priority policies is highly contingent on energy supply security as sustainable, low-carbon energy systems can provide the instruments to achieve these goals.

In addition, the Philippine Development Plan (PDP) 2017-2022 foresees the reduction of poverty, especially in the provinces, and the reduction of unemployment from 5.5 percent at present to as low as 3 percent by 2022 through sustained, robust economic growth in the next six years in line with the vision to make the country a high-income country by 2040 . It also aims to sustain $7-8$ percent GDP growth in the medium-term, and slash poverty incidence to 14 percent by 2022 from 21.6 percent in 2015 . In rural areas, the higher poverty rate of 30 percent in 2015 is expected to be cut to 20 percent in six years' time. Other targets include higher trust in government and society, more resilient individuals and communities, and a greater drive for innovation.

\subsubsection{Energy Security Policies in the Philippines}

Similar to many Asian countries, the GDP growth of the Philippines (average rate of 6.1 percent from 2011 to 2015) is highly contingent on energy-intensive industries, mainly manufacturing and retail (see Euromonitor International 2017). Accounting for 73.5 percent, the energy supply in the country is highly dependent on fossil fuels (coal, gas, and oil). In 2013, coal covered approximately 42.62 percent of electrical energy demand $(75,266 \mathrm{GWh})$. While hydroelectric power accounts for 18 percent, geothermal covers 10 percent of total electricity production. Solar, wind and biomass account for 2 percent of the country's electricity production. Amid a significant increase in the global use of renewable energies, the Philippine government still intends to add 25 additional coal power plants to the current 32 coal-fired power generation facilities in the country (see Quismundo 2016), proving that the country is a laggard in adopting renewable energy technologies.

Energy supply security is also a political priority in the Philippines. The energy crisis in the country is usually at its peak in summer periods, when demand for electricity is high in order to cool and air condition, while the lack of rain reduces electricity generation from hydropower. According to Steven Rood (2015), the major challenge to effectively addressing the energy crisis in the country is its weak governance. Approval for permits could take years, especially when a certain set of applicants are being favored. He notes that the Department of Energy estimates that it takes 165 signatures and a minimum of three years to secure the necessary permits. In addition, Rood suggests that low trust among investors when financing the costs of new power plants is a direct reaction to the 
country's contractual and pricing insecurity. New administrations often renegotiate the terms of contracts made during previous administrations. Government administrations often seek emergency powers to address the energy crisis, but the political opposition often mistrusts such steps. This dependence on emergency powers to implement energy policies vindicates the low autonomy of the State. In addition, the constant need for emergency powers to implement energy policies may reinforce abuse of power, because emergency powers tend to discard guard-rails for accountability and transparency. As such, energy security tends to be a highly political issue in the country and is reduced to the subject of poor governance.

Immediately after his election, President Duterte promised a different and a more proactive approach to addressing the energy crisis in the country. DENR Secretary Lopez announced that she will prioritize the approval of permits for renewable energy projects over those of coal and other fossil fuels. Furthermore, as an environmentalist, she declared her opposition to the opening of the nuclear plant in Bataan, claiming that it will only contribute to less than 0.5 percent to the National Energy Grid with higher costs and risks (Cordero 2017). She suggested that waste-to-energy adoption can be tapped to address the energy crisis while solving waste problems in the country. Meanwhile, Energy Secretary Alfonso Cusi announced in July of 2016 that his team is about to review the country's energy mix, but in the same briefing he also declared that the Philippines "can't afford not to have coal" (Cordero 2017). The Climate Change Commission (CCC) of the Philippines has started its task of reviewing the government's energy policy. In cooperation with various government agencies, a comprehensive review of the government's energy policy involves a whole-nation approach to achieving a low-carbon development pathway, with national goals and targets for climate change mitigation and adaptation, disaster risk reduction, and sustainable development (Climate Change Commission 2016).

The Philippine Energy Plan (PEP) as well as the various sectoral roadmaps 2017-2040, which provide the framework for present and future energy policies, vindicate that the concept of energy security in the Philippines does not yet adequately address how the energy sector will contribute to the reduction of the country's GHG emissions. This is an implication, instead, of the adaptationoriented narratives on climate change in the Philippines. While the Upstream Oil and Gas Roadmap 2017-2040 as well as the Coal Roadmap 2017-2040 provide concrete numbers demonstrating the increased usage of oil, gas and coal, the renewable energy roadmap does not provide any concrete targets in numbers or timelines, implying that energy security will be mostly covered by emission-rich energy sources. 


\subsubsection{Multiple Entry Points to Climate Mitigation and Sustainable Development in the Philippines}

The entry points that will be discussed below do not comprise the complete list of all entry points to climate mitigation in the Philippines. This selection intends to highlight the most relevant ones in the context of system transformation as underscored by the theoretical models (ideal types).

\subsubsection{Rural Development as an Entry Point to Sustainable, Low-Carbon Development}

Because of the current narratives on climate change in the Philippines, additional efforts are needed to find entry points into climate mitigation. Coupling emission reduction with rural development and good governance will most likely find more political and public support than if it would have been presented as a stand-alone issue. For example, rural development will most likely involve the usage of agricultural waste products for bioenergy, as rural communities in the Philippines are highly agricultural. Nevertheless, the concept of waste-to-energy is highly contested in the country, because it is connoted merely with the burning of industrial and household waste. Environmental groups fear the release of toxins from the burning of household and industrial waste. Hence, using agricultural waste for biomass energy will first require its delinking from the current notion of waste-to-energy and waste-to-fertilizer.

Aside from the country's abundant supply of biomass resources (rice, maize, coconut, and sugarcane), agricultural crop residues, forest residues, animal wastes, agro-industrial waste, municipal waste (about 60 percent of which is biomass), and aquatic biomass among others remain unused. From the estimated total agricultural biomass waste in 2012 of $52,568.73$ million metric tons, only 0.054 percent of it is being utilized (Cajes 2014). Merely 1.07 percent of the total biomass resources in the country is being used for energy production. Not only is this surplus waste agricultural biomass, it is a missed opportunity to increase the percentage of biomass, which was at 1.09 percent of the installed capacity (or, as older data shows, at 12.4 percent) of the country's total primary energy supply mix in 2011 (39.4 million tons of oil equivalent (MTOE) (DOE 2017). The estimated biomass required to produce such power is $566,092.8$ metric tons, assuming that the biomass-powered plants run at full capacity (efficiency is 24 percent for large-scale biomass plants ranging from 15 to 60 megawatts). The biofuel roadmap 2017-2040 of the Department of Energy vindicates the peripheral role of bioenergy in the country.

With the highly underutilized resources and agricultural waste products for biomass, the Philippines' can afford to set higher targets for renewable energy's 
contribution to the country's installed generating capacity. Nevertheless, while the Philippines displayed a significant growth in power generation at 10 percent from $82,413,213 \mathrm{MW}$ in 2015 to $90,797,891 \mathrm{MW}$ in 2016 , of this total generation, only 1 percent (or 725,906 MW) comes from biomass. Therefore, additional programs and strategies are needed to complement existing ones to realize higher production targets, to establish market-based industry involving biomass resources including agricultural waste, and to maximize the usage of available international financing schemes such as the Clean Development Mechanism (CDM). Furthermore, partnerships with local sugar producers and farmers are needed, as sugarcane waste covers most of the agricultural waste.

Several programs and projects to promote agricultural biomass waste have been carried out in the Philippines since the 1970s (with an estimated worth of USD 100 million). Based on experiences from previous agricultural waste to energy programs and projects, such efforts can only be successful if they can be adequately coupled with rural development. A significant portion of the efforts have been rated as 'less than successful' by audit reports due to institutional problems, a lack of stakeholder mobilization and beneficiary participation, a lack of human capital in rural areas, as well as due to financial problems such as high initial and maintenance costs (Cajes 2014). These factors indicate the existing gaps between such projects and rural development. Therefore, the success of future programs and projects is highly contingent upon how these deficiencies are properly addressed. Establishing new or promoting old cooperatives and other forms of traditional cooperation methods (e.g., paluwagan) can be beneficial in strengthening 'stakeholder and beneficiary' ownership. New forms of local governance can be identified and tested as these programs and projects are implemented.

\subsection{Case Study_Institutional Activism and Sustainable and Low-Carbon Policy Goals in the 'Weak' Philippine State}

This section pertains to a comparison of the current transformation process in the Philippines as an empirical or historical case and the ideal type of institutional activism. While the sustainable, low-carbon transformation is still at its beginning, it is significant to analyze the challenges of facilitating this transformation. While the low-carbon and sustainability policy goals have already been identified as political priorities, they are still predominantly perceived as isolated policy goals. The interlinkages and the resulting positive and negative synergies between them have yet to be recognized by the relevant policy-makers. The Philippines 
as a case study allows a practical outlook on a transformation process of country that has a very strong civil society which is both a direct result of and an implication of weak governance. The limitations of the state in providing expected services has prompted the state to "resign", and "forge" franchise-like partnerships with civil society groups (see Hernandez 2014a).

\subsubsection{Institutional Activism in the Philippines-The Historical Context and the Party List System}

Activism in the Philippines is connoted with confrontation with state authorities. The historical context of activism in the country links activism to the radicalization of mostly university students after certain violent actions or divisive policies of the government (see Weiss \& Aspinall 2012). Patricio Abinales (1996) highlights the "enduring mark on Philippine society" on the "Philippine Left." Philippine activism is often linked with socialism or communism. The label of "enemy of the state' during the Marcos military regime was used as political leverage to shame and justify the coercive actions of the state, as rural guerrillas, labor unions, community organizers, students and church activists were mobilized, and has become a major political force in the country (Abinales 1996), especially in rural areas. While the end of the military rule of Ferdinand Marcos has allowed activists to take positions in governments, other activists have opted to join the communist insurgency groups in the country.

Institutional activism is not a new phenomenon in the Philippines. As stated earlier, the Philippine political system allows representatives of marginalized groups to be elected to the Philippine Congress through the "party list system" in the House of Representatives of the Philippines. During the interim period from 1987 to 1998 , sectoral representatives were appointed by the President and confirmed by the Commission on Appointments.

During the May 1998 elections, the first sectoral groups were elected. Currently, party-list representatives are indirectly elected when their groups win at least two percent of the national vote, where at least one seat and at most three seats are given, depending on a formula based on the number of votes garnered by the sectoral group. In the last elections in May 2016, eleven party-list groups made the two percent threshold. Winning groups include groups representing women, senior citizens, farmers, teachers, disabled people, overseas Filipinos and the poor (see Uy 2016). The party-list system has allowed activists to mobilize, gain public exposure \& political experience, and, in some cases, these activists were afterwards regularly elected outside the party-list system. 
However, with this "political space" provided to activists, institutional activism in the Philippines typically mainly addresses social capital, good governance and social policies. For example, the party-list system does not include any environmental groups, proving that environmental activism is still traditionally at the periphery of policy-making, and implying that these groups still need to catch up in terms of mobilization. Because of several competing interests with other social groups, environmental groups still need to find their own space which would allow proximity between environmental integrity and social justice.

\subsubsection{Institutional Activism in the Philippines-The Appointment of Secretary Regina Lopez}

The appointment of the activist Regina Lopez as Secretary of the Department of Environment and National Resources was highly contested. Her appointment, and her subsequent failure to acquire confirmation of her appointment from the Commission of Appointments of the House of Representatives, can be seen as a demonstration of the different negotiation processes that need to be adequately prepared for. Several business and industry groups, as well as local government units (LGUs), called her appointment "highly divisive", as she was said to ignore due process anytime it served her vested interests (see Simeon 2017). The Chamber of Mining opposed the claim of Sec. Lopez that she should be able to prohibit mining even in non-proclaimed watersheds (see Quismundo 2017). The Department of Finance, the Department of Labor, and Local Government Units claimed that they were not consulted by Sec. Lopez prior to the closure order (see Catoto 2017).

Eventually, the Commission on Appointments bypassed or deferred the confirmation of her appointment more than once, as many members of the commission expressed opposition to her appointment (Diaz 2016, 2017; Geronimo 2017). The so-called 'preference outliers' or those legislators who were most interested in mining issues actively sought membership in the relevant commission assessing the appointment of the DENR Secretary. Nevertheless, Sec. Lopez was confident that she would be reappointed by President Duterte.

The closure order of more than half of the country's mining companies through DENR and Sec. Lopez had mobilized popular support from various social justice and socio-environmental groups. More than 3,000 members of various anti-mining groups gathered to push for the confirmation of Sec. Lopez as Secretary of DENR (Alvarez 2017a). These groups reprimanded the mining industry by claiming that most Philippine mining operators do not view corporate social responsibility as a major concern. For example, it was argued that mine tailings as waste products without any financial value to the mining operators 
were merely addressed as a financial footnote in the reports of Philippine mining operators. In addition, the environmental group Ibon Foundation claimed that the mining industry does not contribute to local economic development, as regions with the biggest mining activities are among the poorest in the country (Altez 2017).

As expected, the mining industry as well as affected cities and municipalities opposed the cancellation of 'legitimate, large-scale mining projects' which were said to be backed by lawful contracts. The mining industry was also able to mobilize various social groups, which mainly represented local communities affected by the order. On February 16, 2017, some 5,000 workers from different mining companies operating in Surigao del Sur organized a protest urging Sec. Lopez and President Duterte to reconsider closing the mining operations in Surigao del Sur, as this will would have led to massive job loss (Catoto 2017). According to Artemio Disini, head of the Chamber of Mines in the Philippines, more than 219,000 people are directly employed by the mining industry and 1.2 million people indirectly affected. Because 13 of the 28 potentially closed or suspended mines were in Mindanao, this closure order would have mainly affected already poverty-stricken areas of the country (see Altez 2017; Dela Cruz \& Serapio, JR. 2017). The orders to suspend or close down 28 mining operations would have cost local governments a total of more than PHP821.13 million (or ca. USD 15.8 million) a year, according to Finance Secretary Carlos G. Dominguez III (Vera \& Domingo 2017), affecting 17 cities and municipalities in 10 provinces, three of them poised to lose revenues equivalent to more than half of their current operating incomes

In addition, Dindo Manhit (2017) is critical that decisions were made out of "emotional and dramatic harangue(s)" and were made by an environmental activist who sees social justice and environmental issues as "eternally contradictory with prosperity and economics." He adds that the activist politician, and those environmental activists supporting her decisions, were ignoring the USD 840 billion mineral revenues that can also be instrumental in financially achieving social justice and environmental integrity. He adds that while it is true that the mining industry represents only less than one percent of the economy, it should not be disregarded that there are only very few legitimate operating mines in the country, whose footprint reaches barely one percent of the landmass.

Sec. Lopez opted for a competitive negotiation strategy while underestimating the political resources available to the mining sector. Because Sec. Lopez removed the basic symmetry of the negotiatory situation with her mining policies, interest groups representing the mining sector and those local government units negatively affected shifted the bargaining to the hearings of the CA, where she 
could not eliminate procedural equality. In addition, she had no effective leverage in the CA hearings aside from the procedural power of President Duterte, who could re-appoint her any time the CA rejected her confirmation, until the end of his term in 2022. Confronted by this situation, Sec. Lopez brought the "negotiation" to the streets. This strategy is typically used by activists and social movements in the Philippines, usually organizing street protests as instruments for enforcing their influence in policy-making without participating in formal channels. She and her supporters mobilized street protests supporting her anti-mining policies. However, due to the divisive nature of the issues involved, the civil society was fragmented, and she failed to circumvent the polity structures (e.g., the Commission on Appointments) through street protests.

On May 9, 2017, after the rejection of her appointment, President Duterte decided not to reappoint her and instead appointed former military chief Roy Cimatu as the new Environment Secretary (Dizon et al. 2017). Secretary Cimatu eventually overturned the orders of former Sec. Lopez, such as her new policies on the issuance of environmental compliance certificates (ECC) (Gamil 2017). Furthermore, he expressed his intention to address misinformation and 'reverse' the negative publicity around the mining sector (Miraflor 2017).

\subsubsection{An Ideal Type Analysis of Sustainable, Low-Carbon Development in the Philippines}

The evaluation of the sustainable, low-carbon transformation in the Philippines will be conducted through ideal type analysis. The negotiation perspective allows an integrated outlook on the synergies and co-benefits, as well as risks intentionally or unintentionally created by institutional activism. As identified in the theoretical framework, a major assumption of institutional activism is that the results often legitimize the means. An additional assumption is that institutional activism may also seek procedures that are flexible, as defined by power relations, if these changes in procedures facilitate faster policy implementation.

While it is evident that institutional activism has been historically embedded in the political system of the Philippines, with the formalized political inclusion of marginalized sectors of the society into the legislation, there is still a need to understand how institutional activism defines decision-making in the context of weak governance. Similar to authoritarian states, countries with weak governance like the Philippines are often confronted by existing political structures that tend to sustain 'hegemonic' ideas or the dominance of one or several actors and exclude those who oppose the policies of these dominant actors. For example, the 
electoral system in the Philippines employs a 'winner-takes-all' principle, where losing parties are not provided with any formal means of representation. This principle is also reflected in policy-making and policy implementation, where public deliberation is only tolerated or even encouraged when it supports government policies. Opposing actors are put off and the reference to the rule of law is then highlighted. Furthermore, weak governance in the Philippines is expressed by 'franchising' various key government responsibilities to 'elite groups', including oligarchs and corporations (see Hernandez 2014a). Similarly, the presence of political dynasties, where one family has its members both in the political and business fields to ensure that their interests are always protected, hampers changes. In this context, regaining these responsibilities will first require revisions to the social contract.

The election of President Duterte has led to new and often paradoxical dynamics in Philippine politics. On the one hand, while the administration has employed authoritarian principles in implementing its policies, such as the concentration of state authority on executive institutions as well as penalizing representatives in the Congress and senators who do not support government policies by stripping them of key posts (see ABS-CBN News 2017; Morallo 2017), such moves are regarded as facilitating a more rapid formulation and implementation of policies. On the other hand, the government (including the DENR) has often resorted to the mobilization of citizen groups in order to support government policies which may not adhere to the rule of law and also to discredit political opposition. As the ideal type suggests, the relation between the policy-politics stream the and polity stream can be adversarial, especially when bureaucracy limits the pace of policy-making and policy implementation. Ironically, the Philippine government is not only instrumentalizing this bureaucracy to exclude opposition, but it also seeks to circumvent this bureaucracy when it is not beneficial to the government's interests.

Stream-alignment is defined by decisions reached more rapidly because of the exclusionary nature of agenda-setting. Although the confirmation of the appointment of DENR Secretary Regina Lopez was still pending, during her first months as secretary of the Department of Environment and Natural Resources she was inclined to dominate agenda-setting, and other actors were not formally given the chance to express their perspectives (see Cordero 2017; Alvarez 2017b). Looking at the ideal type of institutional activism, then, Sec. Lopez pushed her adversaries out of the policy-making sphere, allowing them no formal channels with which to dissent. What followed was that these opposing actors sought other bargaining avenues as they became aware that the "bargaining table" set by Sec. Lopez did not allow for bargaining at all, as former Sec. Lopez was not seen as being prepared to accept compromises. As Sec. Lopez had already employed a highly 
'competitive' negotiation style, other actors sought to shift the forum and establish another 'bargaining table' that would have either excluded her or limited her prerogatives. Industry actors had already foreclosed on the possibility of working together with Sec. Lopez (see Simeon 2017). This led to the situation where a specific issue (here, mining) completely defined the course of the process (instead of the process defining the scope of the issues and how those issues should have been addressed), which produced negative-sum results, not only in mining policies, but also in other issues.

Former Sec. Lopez' actions confirmed that institutional activism focuses on issues and outcomes rather than on processes. In the context of key economic sectors 'franchised' to corporations and business groups, focusing on the process, for instance, would have witnessed Sec. Lopez first seeking to alter the playing field in order to change the rules of the game that had hitherto favored business and industry actors. Instead, she used the concentration of state authority in executive institutions to push for her environmental policies. In light of huge opposition, she used instruments typical of activist groups such as mass mobilization and aggressive rhetoric defaming mining groups as 'environmental rapists' and opposing politicians as 'killing mountains' (see Quismundo 2017; Simeon 2017). From the negotiation perspective, labelling other actors as the problem limits the sets of possible outcomes that are acceptable to all. The Philippine Business for Environmental Stewardship (PBEST), an environmental NGO advocating for the compliance of the country's businesses with al environmental rules and regulations, argued that 'responsible mining exists in the Philippines' (Business Mirror 2016). PBEST explained that instead of being branded as the enemy of the environment, the mining industry could be seen as the actor that could (and should) provide resources and a culture of innovation to solve environmental problems.

Furthermore, the role of science has been reduced to that of mere instrument. This gave groups opposing Sec. Lopez the possibility to claim that decisions made by her were merely based on ideologies rather than on scientific evidence (see Tria 2017; Alvarez 2017b). Carlos David argues that statements by Sec. Lopez may be understandable as claims from advocates, but it sends the wrong message when it comes from the head of the DENR (Business Mirror 2016), as it oriented the mining industry as part of the problem and not the solution. In addition, due to structural limitations, academic discourse in the Philippines tends to move outside the "typical channels" of scholarly debate such as peer-reviewed journals and conferences. As Filipino scholars are considered "periphery scholars" (Belcher 2009) with limited access to journals, debates are often conducted through opinion columns and sections of the newspapers, where academics and experts are able to quickly engage in public debate. 
Looking at the case of institutional activism in the Philippines and how it compared to the ideal type, the context of (weak) governance in the country suggests that in order to facilitate sustainable, low-carbon transformation, major changes in governance structures are needed. The institutional activism of former Secretary Lopez elucidates that policy-making in the country focuses strongly on specific issues (rather than processes) that foreground negative-sum outcomes inhibiting possible synergies and trade-offs between issues. In addition, should Sec. Lopez have been successful in implementing her policies, it would have been a big question as to whether these policies would even have been institutionalized at all, especially after the administration of President Duterte when a new government administration comes into power in 2022. It is more likely that her policies would have been completely reverted, thus implying a return to default, further contributing to uncertainties and vacuums. In addition, as she was seeking to change the mandate of her government agency (from a regulatory to a development agency), she was also changing the internal functions and the qualifications needed for those placed in the agency. Doing so would have required her to deal with how to make a productive government office with people who may not have been in the right type of work due to the abrupt changes she made.

\subsection{Conclusion-Lessons for Theory and for Practice}

\subsubsection{Lessons for Theory}

The theoretical framework of the case study on the Philippines has provided an understanding of how institutional activism can both inhibit and promote sustainable, low-carbon transformation. Looking at the 'negotiative' requirement of sustainable, low-carbon transformation, the benefits and risks of institutional activism are highly contingent upon existing power relations and structures as well as on the level of capacity and autonomy of the state. While institutional activism can facilitate rapid policy formulation, it can also use bureaucratic leverage to reinforce existing inequalities in countries with low social capital. Because institutional activism uses the same structures that have created such inequalities in the first place, institutional activism may reinforce authoritarianism by excluding other interests and finding ways to legitimize such actions through means outside of the legal framework, such as social networks.

Institutional activism may also have negative implications for democracy and participation. It may, for example, further weaken social movements. Because satisfying all social groups is not possible, institutional activists may proactively 
seek to exclude other social groups that seek interests that oppose government policies. Therefore, institutional activism may unintentionally create new 'social elites' who will further weaken social movements, as disfranchised social groups will distance themselves from these social elites. In the case of the Philippines, environmental groups, for example, which are seeking to enhance the use of renewable energy will be easily labelled as 'ecological elites', delegitimizing the goals of these groups in the eyes of other disfranchised social groups. This development will most likely undermine the transformation process, especially because cooperation between these groups is inevitable. Furthermore, institutional activism may induce violence as adversaries are not given effective political channels, especially when decisions, such as the closure of mines, will be linked to the realm of the personal, such as livelihoods and incomes of households.

Furthermore, disfranchising (previously powerful) stakeholders such as business and industry groups is counterproductive, as this will provide these groups with additional resources to act as "spoilers" who, when outside the policy-making process, are not bounded by the norms and rules of negotiations or consensus-building. Labelling them as the problem is not helpful, as it will prevent them from contributing to solutions. Like authoritarian policy models, institutional activism may also cause poor policy formulation and poor policy implementation, as these policies will most likely be challenged or reversed after the administration changes. Furthermore, institutional activism may decrease the threshold for future political abuse, as it provides "undemocratic practices" in democratic political regimes with more resources to legitimize undemocratic actions through social networks and concentrated executive power. Especially in democratic countries with weak governance structures like the Philippines, institutional activism can motivate policy-makers addressing other issues to resort to similar authoritarian actions, especially when there is substantial opposition. Ignoring the principles of the "rule of the law" and due process as long as legitimizing factors can be found to support such actions creates precedents for future authoritarian practices. Therefore, environmentalism should also be subjected to formal and material democratic principles.

\subsubsection{Lessons for Practice}

The strategy of Sec. Lopez in eliminating the negotiatory or bargaining aspect of environmental policy-making was successful in eliminating reciprocity in this specific policy game. The absence of initial inequality in power motivated the mining and industry sector to shift the bargaining process to a forum where they 
could have procedural inequality. This was possible because of the monolithic architecture of policy-making frameworks. As Sec. Lopez adopted the strategy of "demonizing" the mining and industry sector, the latter reciprocated and provided arguments that saw Sec. Lopez as the problem. Sec. Lopez's appointment and her subsequent failure to acquire confirmation of her appointment from the Commission of Appointments of the House of Representatives can be seen as a demonstration of the different negotiation processes that need to be adequately prepared for.

Policies and polities should be separated from politics or, if not, should be above politics. While policies should reflect consensual processes, polities guarantee the rules of the game. Politics brings the dynamics in process, as new agendas are identified, or existing norms revisited following the emergence of system pressures due to incremental changes. Nevertheless, this can only function when those in power 'respect' the boundaries between streams. If this is not the case, the pragmatic approach is to 'go with the flow' and for those actors in the polities and politics stream to find ways of embedding themselves in the policies stream.

The Philippine case study demonstrates the importance of social movements, activists, and non-profits as advocates. It also shows that these groups are not resistant to existing structural privileges, particularly when these privileges allow them to purportedly achieve their goals. However, as Bass et al. (2014) claims, advocacy is about relationships and about changing power dynamics. These groups should not forget their initial mandate and should look at how existing structures are responsible for the inequalities that mobilized them in the first place. When in power, like in the Philippines, they should seek to alter relationships and change power dynamics.

Open Access This chapter is licensed under the terms of the Creative Commons Attribution 4.0 International License (http://creativecommons.org/licenses/by/4.0/), which permits use, sharing, adaptation, distribution and reproduction in any medium or format, as long as you give appropriate credit to the original author(s) and the source, provide a link to the Creative Commons license and indicate if changes were made.

The images or other third party material in this chapter are included in the chapter's Creative Commons license, unless indicated otherwise in a credit line to the material. If material is not included in the chapter's Creative Commons license and your intended use is not permitted by statutory regulation or exceeds the permitted use, you will need to obtain permission directly from the copyright holder.

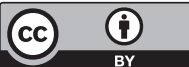

